\title{
Phylogenetic analysis, biofilm production, and antimicrobial resistance profile of Escherichia coli isolated from slaughtered pigs
}

\author{
[Análise filogenética, produção de biofilme e perfil de resistência antimicrobiana de Escherichia
} coli isoladas de suínos abatidos]

\author{
A.S. Santos ${ }^{1}$, D.C.V. Lima $^{1}$, E.F.T.S. Fernandes ${ }^{1}$, P.P.F. Albuquerque ${ }^{1}$, G.V. Gouveia ${ }^{2}$, M.C.A. Sá ${ }^{2}$, \\ M.M. Costa ${ }^{2}$, J.W. Pinheiro Júnior ${ }^{1}$, R.A. Mota ${ }^{1}$ \\ ${ }^{1}$ Universidade Federal Rural de Pernambuco - Recife, PE \\ ${ }^{2}$ Universidade Federal do Vale do São Francisco - Petrolina, PE
}

\begin{abstract}
Enteric diseases of bacterial origin are frequent in the pig industry, of particular notoriety are the colibacillosis that mainly affect piglets and cause great damage to the swine industry worldwide. The aim of the study was to analyze phylogenetics, to detect biofilm production, and to determine antimicrobial resistance profile in 126 strains of Escherichia coli isolated from swabs obtained from fragments of the small intestines of 235 healthy pigs killed in slaughterhouses in Pernambuco (Brazil) using polymerase chain reaction (PCR), adherence to microplates test and disc diffusion technique. Of the analyzed samples, $88.10 \%$ (111/126) were classified in phylogenetic group B1; $4.76 \%(6 / 126)$ in group D; 3.97\% $(5 / 126)$ in group B2 and, 3.17\% (4/126) in group A. Antimicrobial resistance rates observed were: lincomycin 100\% (126/126), erythromycin 100\% (126/126), chlortetracycline 94.44\% (119/126), cephalothin 51.59\% (65/126), ampicillin 38.89\% (49/126), sulfamethoxazole + trimethoprim 37.3\% (47/126), ciprofloxacin 19.84\% (25/126), norfloxacin $14.29 \%$ (18/126), gentamicin 8.73\% (11/126) and, chloramphenicol 5.55\% (7/126). Multiple antibiotic resistance (MAR) ranged from 0.2 to 0.9. Of the strains tested $46.03 \%$ (58/126) produced biofilm, and 99.21\% (125/126) of the strains exhibited multiresistance. Further studies are required to elucidate the importance of each phylogenetic group in pigs and to prevent the propagation of multi-resistant E. coli strains.
\end{abstract}

Keywords: pig industry, colibacillosis, phylogeny, antibiogram, multi-resistance

\section{RESUMO}

Doenças entéricas de origem bacteriana são frequentes na indústria de suínos, destacando-se a colibacilose, que afeta principalmente leitões e causa grandes danos à indústria suína em todo o mundo. Cento e vinte e seis cepas de Escherichia coli foram isoladas de swabs obtidos de fragmentos de intestino delgado de 235 suínos saudáveis abatidos em matadouros de Pernambuco (Brasil). O objetivo do presente estudo foi analisar filogeneticamente essas cepas, bem como detectar a produção de biofilme e determinar o perfil de resistência antimicrobiana delas, utilizando-se a reação em cadeia da polimerase (PCR), o teste de adesão em microplacas e a técnica de disco-difusão. 88,10\% (111/126) das amostras foram classificadas no grupo filogenético B1; 4,76\% (6/126) no grupo D; 3,97\% (5/126) no grupo B2; e $3,17 \%$ (4/126) no grupo A. As taxas de resistência antimicrobiana observadas foram: lincomicina $100 \%$ (126/126), eritromicina 100\% (126/126), clortetraciclina 94,44\% (119/126), cefalotina 51,59\% (65/126), ampicilina 38,89\% (49/126), sulfametoxazol + trimetoprima 37,3\% (47/126), ciprofloxacina 19,84\% (25/126), norfloxacina 14,29\% (18/126), gentamicina 8,73\% (11/126) e cloranfenicol 5,55\% (7/126). O indice de resistência múltipla (IRMA) variou de 0,2 a 0,9. Entre as amostras, 46,03\% (58/126) produziram biofilme e 99,21\% (125/126) foram multirresistentes. São necessários mais estudos para elucidar a importância de cada grupo filogenético em suinos e evitar a propagação de estirpes de E. coli multirresistentes.

Palavras-chave: indústria suína, colibacilose, filogenia, antibiograma, multirresistência

Recebido em 29 de março de 2017

Aceito em 22 de novembro de 2017

E-mail: andresouza_santos@hotmail.com 


\section{INTRODUCTION}

The production of pork in Brazil in 2016 moved US \$ 1.48 billion only with exports, an increase of $16 \%$ compared to 2015 , demonstrating the economic importance of this activity, especially in the south of the country (ABPA, 2017). The Northeast region has been increasing its participation in pork production and, in this context, the state of Pernambuco has been increasing its herd over the years (ABPA, 2017). Enteric diseases of bacterial origin, such as colibacillosis, have a great economic impact on the pig industry, due to the high rates of morbidity and mortality, as well as the sequels in the gastrointestinal tract and expenses related to antibiotic therapy (Menin et al., 2008).

Colibacillosis is an enteric disease that mainly affects neonatal and post-weaning piglets. It is caused by toxigenic strains of Escherichia coli, which is one of the main causes of diarrhea among pigs (Zhang and Francis, 2010).

Strains of Escherichia coli can be classified into four main phylogenetic groups (A, B1, B2 and D). The most virulent strains belong to groups B2 and D, whereas strains considered commensal are often classified in groups A and B1 (Clermont et al., 2000; Moreno et al., 2006).

Bacterial resistance to antimicrobials is a serious problem in both human and veterinary medicine. Rational use of antimicrobial drugs must be made in order to avoid resistant bacteria in animals, humans or in the environment. Furthermore, the abuse of antimicrobials, including growth promotes, leads to an accumulation of antibiotic residues in the meat of the animals, which will later be consumed by humans that may cause hypersensitive reactions and expose the natural microbiota to these agents (Machado et al., 2016).

The capacity of a microorganism to produce biofilm is associated with the increase in resistance to antimicrobial agents. It is estimated that biofilm cells are between 100 and 1000 times more resistant to antimicrobial agents than planktonic bacterial cells, which is a significant problem in the treatment of chronic infections (Qi et al., 2016).
In the Northeast of Brazil, data about the sanitary profile of pig herds are scarce and there is no information about the characterization of $E$. coli strains in herds. Therefore, the aim of this study was to analyze phylogenetically, the production of biofilm and determine the resistance profile of antimicrobials among $E$. coli strains isolated from pigs killed for human consumption in slaughterhouses in the state of Pernambuco, Brazil.

\section{MATERIALS AND METHODS}

The present study was submitted to the Animal Rights Ethics Committee of the Universidade Federal Rural de Pernambuco under process number 23082.005013/2013-31 and it was approved under license number $032 / 2013$ on April 29, 2013.

In total, 126 Escherichia coli strains were used in the present study. The strains were isolated from swabs obtained from fragments of the small intestines of 235 pigs. These fragments were collected at the time of evisceration, during their slaughter in public slaughterhouses, with one swab for each animal. These swabs were identified and stored in cool boxes containing recyclable ice before being sent to the Infectious Diseases Laboratory (LDIC) in the Universidade Federal Rural de Pernambuco (UFRPE), where they were processed.

In the laboratory, they were seeded on MacConkey agar culture media $\left(\mathrm{MERCK}^{\circledR}\right.$, Jacarepaguá, RJ, Brazil) and incubated at $37^{\circ} \mathrm{C}$ for 24 to 48 hours. Characteristic strains were submitted to Gram staining technique and, later, the Gram-negative samples were submitted to biochemical tests, such as lactose fermentation, d-manitol fermentation, acid from glucose with gas, hydrogen sulfide negative, indole production, Voges-Proskauer test, Simmons citrate and lysin decarboxylase. After the biochemical confirmation, each colony was stored in cryovials of $2 \mathrm{~mL}$, containing brain heart infusion broth (BHI) $\left(\mathrm{MERCK}^{\circledR}\right.$, Jacarepaguá, RJ, Brazil) and glycerol. They were then stored at $-20^{\circ} \mathrm{C}$ until its processing.

The phylogenetic characterization of the E. coli strains was conducted following the methodology described by Clermont et al. (2000). The DNA of the isolates was thermally 
extracted as described by Sá et al. (2013). Afterwards, the amplification of the chuA (279bp) and yjaA (211bp) genes and the DNA fragment TspE4.C2 (152bp) was carried out, the primers of which are displayed in Tab. 1. The reactions were executed in a volume of $25 \mu \mathrm{L}$ per microtubule, containing 100ng of DNA template, the primers (30pmol each), Taq buffer $(10 \mathrm{mM}$ Tris, $50 \mathrm{mM} \mathrm{KCl}, 2.5 \mathrm{mM} \mathrm{MgCl} 2), 200 \mathrm{mM}$
dNTPs and 1U Taq DNA polymerase $\left(\right.$ Cenbiot $^{\circledR}$, Taq. DNA polymerase, Ludwig Biotec, Porto Alegre, RS, Brazil). The thermal profile of the reactions involved an initial phase of $4 \mathrm{~min}$ at $94^{\circ}$, followed by 30 cycles of denaturation at $94^{\circ} \mathrm{C}$ for $30 \mathrm{~s}$, annealing at $55^{\circ} \mathrm{C}$ for $30 \mathrm{~s}$ and extension at $72^{\circ} \mathrm{C}$ for $30 \mathrm{~s}$. The final step involved a final extension at $72^{\circ} \mathrm{C}$ for $7 \mathrm{~min}$.

Table 1. Sequences of the primers and size of the amplicons in base pairs (bp) observed in the PCR for the phylogenetic study

\begin{tabular}{ccc}
\hline Target & Sequence $\left(5^{\prime}-3^{\prime}\right)$ & Products $(\mathrm{bp})$ \\
\multirow{2}{*}{ chuA } & F - GACGAACCAACGGTCAGGAT & 279 \\
& R - TGCCGCCAGTACCAAAGACA & 211 \\
yjaA & F - TGAAGTGTCAGGAGACGCTG & \\
TspE4.C2 & R - ATGGAGAATGCGTTCCTCAAC & 152 \\
\hline
\end{tabular}

Source: Clermont et al. (2000).

PCR products were submitted to electrophoresis in agarose gel at $1.5 \%$, stained with ethidium bromide, visualized in ultraviolet light and photodocumented. Depending on the combination of markers observed the isolates were classified in one of the four phylogenetic groups (A, B1, B2 and D).

Before performing the biofilm production tests, previously frozen strains were cultured in nutrient agar (HIMEDIA ${ }^{\circledR}$, Curitiba, PR, Brasil) for $24 \mathrm{~h}$ and adjusted to $0.5 \mathrm{McF}$ arland units $(\sim 1.5 \times 108 \mathrm{CFU} / \mathrm{mL})$ with $0.85 \% \mathrm{NaCl}$ medium. This step eliminated the glycerol present in cryopreservation, which could interfere with increasing optical density (O.D.) in the next steps. Then, biofilm formation was detected by testing the adherence to microplates, as described by Merino et al. (2009). Optical density (OD) of the samples was determined by a microplate reader (Biochrom Expert Plus Asys ${ }^{\circledR}$, Holliston, MA, USA) and measured with a wavelength of $595 \mathrm{~nm}$. All of the isolates were tested in triplicate using the E. coli ATCC 35218 strain as a positive control and the Luria Bertani medium (HIMEDIA ${ }^{\circledR}$, Curitiba, PR, Brasil) as a negative control. Based on the arithmetic mean of the OD of the triplicates of the isolates, the OD produced by each isolate was obtained $\left(\mathrm{OD}_{\mathrm{i}}\right)$. After comparing the $\mathrm{OD}_{\mathrm{i}}$ and the mean OD produced by the negative control $\left(\mathrm{OD}_{\mathrm{c}}\right)$, the micro-organisms were grouped as follows: nonformer of biofilm $\left(\mathrm{OD}_{\mathrm{i}} \leq \mathrm{OD}_{\mathrm{c}}\right)$; weak $\left(\mathrm{OD}_{\mathrm{c}} \leq \mathrm{OD}_{\mathrm{i}}\right.$ $\left.\leq 2 \mathrm{xOD}_{\mathrm{c}}\right)$, moderate $\left(\mathrm{OD}_{\mathrm{c}} \leq \mathrm{OD}_{\mathrm{i}} \leq 4 \mathrm{xOD}_{\mathrm{c}}\right)$ or strong $\left(\mathrm{OD}_{\mathrm{i}}>4 \mathrm{xOD} \mathrm{C}_{\mathrm{c}}\right)$ former of biofilm (Stepanovic et al., 2000).

The resistance profile of the antimicrobials was determined by the disk diffusion method (Baccaro et al., 2002). This involved testing antimicrobials commonly used in the pig industry (Costa et al., 2006; Drummond and

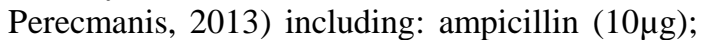
cephalothin $(30 \mu \mathrm{g})$; ciprofloxacin $(5 \mu \mathrm{g})$; chloramphenicol $(30 \mu \mathrm{g})$; chlortetracycline $(15 \mu \mathrm{g}) ; \quad$ erythromycin $(15 \mu \mathrm{g}) ; \quad$ gentamicin $(10 \mu \mathrm{g})$; norfloxacin $(10 \mu \mathrm{g})$; lincomycin $(2 \mu \mathrm{g})$ and sulphazotrim (sulfamethoxazole + trimethoprim) $(25 \mu \mathrm{g})$. The results were interpreted after reading the halos of inhibition observed (Performance..., 2013). The multiple antibiotic resistance index (MAR) was calculated considering strains with an MAR value greater than 0.2 as multi-resistant, as described by Krumperman (1983).

\section{RESULTS}

Of the 126 strains of E. coli analyzed, $3.17 \%$ (4/126) were classified in the phylogenetic group A, whereas $88.10 \%(111 / 126)$ were classified in group B1, totaling $91.27 \%(115 / 126)$ of the strains classified in phylogenetic groups considered commensal. The B2 and D groups accounted for $3.97 \%(5 / 126)$ and $4.76 \%(6 / 126)$ of the strains, respectively, totaling $8.73 \%$ 
$(11 / 126)$ of the strains classified in phylogenetic groups considered virulent.

With regards to the test of resistance to antimicrobials, $100 \%$ of the strains were resistant to at least two of the antimicrobials tested and $80.16 \%(101 / 126)$ were resistant to at least four antimicrobials. The resistance profile of the antimicrobials tested was $5.55 \%(7 / 126)$ for chloramphenicol, followed by gentamicin with $8.73 \%$ (11/126), norfloxacin with $14.29 \%$ (18/126), ciprofloxacin with $19.84 \%$ (25/126), sulfamethoxazole + trimethoprim with $37.3 \%$ (47/126), ampicillin with $38.89 \%$ (49/126), cephalothin with $51.59 \% \quad(65 / 126)$, chlortetracycline with $94.44 \% \quad(119 / 126)$, erythromycin and lincomycin with $100 \%$ $(126 / 126)$ of the strains resistant to both.

The MAR ranged from 0.2 to 0.9 with a mean result of 0.47 . The phylogenetic groups $\mathrm{A}$ and $\mathrm{B} 1$ exhibited mean indices of 0.58 and 0.47 , respectively, whereas the mean MAR in the B2 group was 0.44 and in the $\mathrm{D}$ group was 0.43 .

Among all of the strains tested, $46.03 \%(58 / 126)$ produced biofilm. Of these, $84.48 \%$ (49/58) were weak, $13.80 \%(8 / 58)$ were moderate and $1.72 \%$ (1/58) were strong formers of biofilm. Biofilm results according to phylogenetic groups distribution are exposed in Tab. 2.

Table 2. Results of biofilm production according to phylogenetic group

\begin{tabular}{cccccc}
\hline \multirow{2}{*}{$\begin{array}{c}\text { Phylogenetic } \\
\text { group }\end{array}$} & $\mathrm{N}$ & $\mathrm{W}$ & $\mathrm{M}$ & $\mathrm{S}$ & Total \\
\cline { 2 - 5 } & A.F. (\%) & A.F. (\%) & A.F. (\%) & A.F. (\%) & A.F. (\%) \\
\cline { 2 - 5 } A & $1(0.8)$ & $3(2.4)$ & - & - & $4(3.2)$ \\
B1 & $59(46.8)$ & $43(34.1)$ & $8(6.3)$ & $1(0.8)$ & $111(88.0)$ \\
B2 & $4(3.2)$ & $1(0.8)$ & - & - & $5(4.0)$ \\
D & $4(3.2)$ & $2(1.6)$ & - & - & $6(4.8)$ \\
Total & $68(54.0)$ & $49(38.9)$ & $8(6.3)$ & $1(0.8)$ & $126(100)$ \\
\hline
\end{tabular}

N-negative; W-weak; M-moderate; S-strong; A.F.-Absolute frequency; \%-percentage.

\section{DISCUSSION}

In the present study, $91.27 \%(115 / 126)$ of the strains analyzed belonged to the phylogenetic groups A or B1, which corroborates the findings of Wang et al. (2010) and Mohamadi et al. (2015), who used isolated strains of piglets with diarrhea and healthy ostrich, respectively, and found a greater frequency of the isolates belonging to the phylogenetic groups considered commensal. Previous studies with isolates of $E$. coli have shown that the pathogenic strains isolated from pigs and cattle are mostly classified in the phylogenetic groups $\mathrm{A}$ and $\mathrm{B} 1$, whereas isolates from poultry belong to groups $\mathrm{A}, \mathrm{B} 1$ and D (Girardini et al., 2012, Mohamadi et al., 2015) and human isolates mainly belong to groups A and B2 (Bailey et al., 2010).

Although several authors have stated that the phylogenetic groups A and B1 are commensal (Clermont et al., 2000; Moreno et al., 2006; Moulin-Schouleur et al., 2007), Ramos et al. (2013) has shown that these phylogenetic groups are more common among strains isolated from pigs with diarrhea, suggesting that groups A and B1 have a greater pathogenic importance among pigs.

According to Lay et al. (2012), it is essential to perform an antibiogram for $E$. coli, considering ecological, environmental and genetic factors, due to the high frequency of isolates resistant to the majority of antimicrobials. This was observed in the present study, in which $99.21 \%$ $(125 / 126)$ of the strains exhibited multiresistance, which is a similar result to that obtained by Krewer et al. (2012), who reported that this result could indicate the potential for horizontal transfer of resistance genes.

Mota et al. (2005) reported that high rates of multiple resistance to antimicrobials represent a great risk to public health by hindering the treatment of animal and human diseases. According to the same authors, in different production systems of the region studied, there is indiscriminate use of antimicrobials without veterinary supervision, which could aggravate the multi-resistance situation. 
The results of the present study corroborate the findings of Drummond and Perecmanis (2013) that also reported $100 \%$ resistance to erythromycin and lincomycin, while also confirming that ciprofloxacin, norfloxacin and gentamicin were the drugs with the greatest in vitro efficacy.

The index of resistance found for chloramphenicol $(5.55 \%)$ in the present study demonstrated the decreasing tendency of resistance to this drug in comparison to previous studies conducted in Brazil. Baccaro et al. (2002) recorded $97 \%$ of strains resistant to this antimicrobial when analyzing $600 \mathrm{E}$. coli isolates from piglets with diarrhea in the state of São Paulo. Ten years later, Krewer et al. (2012) analyzed 62 isolates of $E$. coli from the feces of pigs in the south of Brazil and found that $16.3 \%$ of the samples were resistant to this active ingredient. This behavior could be explained by a determination from the Ministry of Agriculture, Fishing and Supplies (Normative Instruction no. 38 from the 8th of May 2002), which prohibited the fabrication, importation, and commercialization of chloramphenicol, nitrofurans and products that contained these active ingredients for use in veterinary medical. This could have interrupted the selection cycle of resistant strains, as witnessed with tetracyclines, which are widely used in the prophylaxis of diarrhea and used as growth promoters in the pig industry.

For the isolates analyzed in the present study, the MAR recorded was similar for the four phylogenetic groups, although it is expected that strains from animals that do not belong to the group B2 exhibit less virulence factors and more antimicrobial resistance, which would be explained by geographic variations and individual characteristics of the host, as reported by Sabaté et al. (2008).

Data referring to the production of biofilm by $E$. coli strains isolated from animals are scarce (Melchior et al., 2006). However, its importance in the pig industry is well known, particularly as it makes biofilm producing microorganisms more resistant to the action of antimicrobials and disinfectants (Reisner et al., 2006). The results obtained in the present study, in which $46.03 \%$
$(58 / 126)$ of the strains were biofilm producers, differ from those reported by Fernandes et al. (2011) who analyzed strains from bovine mastitis and confirmed that $100 \%$ of the E. coli isolates tested were capable of producing biofilm. However, when comparing the distribution by phylogenetic group, the results are similar in terms of groups A and B1 being the most common. The results of the present study also differ from those reported by Conceição (2010), who studied E. coli strains associated with sepsis in humans and detected biofilm production in $81.7 \%$ of the isolates.

Previous studies conducted by Ito et al. (2009) and Ponnusamy et al. (2012) have shown an association between the production of biofilm and antimicrobial resistance. According to Kumar and Anand (1998), this association is caused by physiological and structural alterations that occur in bacterial cells, including the production of enzymes that degrade antimicrobial substances, the reduction of bacterial growth rates and the formation of layers of bacterial cells that prevent contact between antimicrobial drugs and the cells of the deepest layers, which are associated with persistent infections and represent a risk to public and animal health (Hoiby et al., 2010).

\section{CONCLUSION}

Multi-resistance to antimicrobials is disseminated among strains of E. coli, although the vast majority of them are considered commensal. Thus, the transmission of these micro-organisms to humans poses a serious risk to public health as well as to other animal species. Further studies are required to elucidate the importance of each phylogenetic group to pigs and to prevent the propagation of multiresistant $E$. coli, which may be an important pathogen for several species.

\section{ACKNOWLEDGEMENTS}

The authors would like to thank the Fundação de Amparo à Ciência e Tecnologia do Estado de Pernambuco (FACEPE) for the scholarship granted (IBPG-0400-5.05/11) and mobility assistance (AMD-0026-5.05/13), which enabled the execution of the present study. 


\section{REFERENCES}

BACCARO, M.R.; MORENO, A.M.; CORRÊA, A. et al. Resistência antimicrobiana de amostras de Escherichia coli isoladas de fezes de leitões com diarreia. Arq. Inst. Biol., v.69, p.15-18, 2002 .

BAILEY, J.K.; PINYON, J.L.; ANANTHAM, S. et al. Distribution of human commensal Escherichia coli phylogenetic groups. J. Clin. Microbiol., v.48, p.3455-3456, 2010.

CLERMONT, O.; BONACORSI, S.; BINGEN, E. Rapid and simple determination of the Escherichia coli phylogenetic group. Appl. Environ. Microbiol., v.66, p.4555-4558, 2000.

CONCEIÇÃO, R.A. Formação de biofilme em amostras de Escherichia coli associada à sepse (SEPEC): caracterização fenotípica, genotípica e filogenia. 2010. 66f. Dissertação (Mestrado em Genética e Biologia Molecular) - Instituto de Biologia, Universidade Estadual de Campinas, Campinas, SP.

COSTA, M.M.; SILVA, M.S.; SPRICIGO, D.A. et al. Caracterização epidemiológica, molecular e perfil de resistência aos antimicrobianos de Escherichia coli isoladas de criatórios suínos do Sul do Brasil. Pesqui. Vet. Bras., v.26, p.5-8, 2006.

DRUMMOND, V.O.; PERECMANIS, S. Genes de enterotoxinas e perfil antimicrobiano de Escherichia coli isoladas de suínos hígidos no Distrito Federal. Arq. Bras. Med. Vet. Zootec., v.65, p.1005-1009, 2013.

FERNANDES， J.B.C.; ZANARDO， L.G.; GALVÃO, N.N. et al. Escherichia coli from clinical mastitis: serotypes and virulence factors. J. Vet. Diagn. Invest., v.23, p.1146-1152, 2011.

GIRARDINI, L.K.; SIQUEIRA, F.M.; KREWER, C.C. et al. Phylogenetic and pathotype analysis of Escherichia coli swine isolates from Southern Brazil. Pesqui. Vet. Bras., v.32, p.374-378, 2012.

HOIBY, N.; BJARNSHOLT, T.; GIVSKOV, M et al. Antibiotic resistance of bacterial biofilms. Int. J. Antimicrobiol. Agents, v.35, p.322-332, 2010 .
ITO, A.; TANIUCHI, A.; MAY, T. et al. Increased antibiotic resistance of Escherichia coli in mature biofilms. Appl. Environ. Microbiol., v.75, p.4093-4100, 2009.

KREWER, C.C.; GRESSLER, L.T.; COSTA, M.M. et al. Suscetibilidade a desinfetantes e perfil de resistência a antimicrobianos em isolados de Escherichia coli. Pesqui. Vet. Bras., v.32, p.1116-1120, 2012.

KRUMPERMAN, P.H. Multiple antibiotic resistance indexing of Escherichia coli to identify high-risk sources of fecal contamination of foods. Appl. Environ. Microbiol., v.46, p.165$170,1983$.

KUMAR, C.G.; ANAND, S.K. Significance of microbial biofilms in food industry: a review. Int. J. Food. Microbiol., v.42, p.9-27, 1998.

LAY, K.K.; KOOWATTANANUKUL， C.; CHANSONG, N. et al. Antimicrobial resistance, virulence, and phylogenetic characteristics of Escherichia coli isolates from Clinically Healthy Swine. Foodborne Pathog. Dis., v.9, p.992-1001, 2012.

MACHADO, G.B.; MOURA, S.V.; FORTES, T.P. et al. Impacto da salmonelose na suinocultura e suas implicações em saúde pública. Arq. Inst. Biol., v.83, p.1-5, 2016.

MELCHIOR, M.B.; VAARKAMP, H.; FINKGREMMELS, J. Biofilms: a role in recurrent mastitis infections? Vet. J., v.171, p.398-407, 2006.

MENIN, A.; RECK, C.; SOUZA, D. et al. Agentes bacterianos enteropatogênicos em suínos de diferentes faixas etárias e perfil de resistência a antimicrobianos de cepas de Escherichia coli e Salmonella spp. Ciênc. Rural, v.38, p.1687-1693, 2008.

MERINO, N.; TOLEDO-ARANA, A.; VERGARA-IRIGARAY, M. et al. Protein Amediated multicellular behavior in Staphylococcus aureus. J. Bacteriol., v.191, p.832-843, 2009.

MOHAMADI E; ALIZADE, H.; ASKARI, N. et al. antibiotic resistance profile in relation to phylogenetic background in Escherichia coli isolated from fecal samples of healthy ostrich. Int. J. Enteric Pathog., v.3, e25366, 2015. 
MORENO, E.; PRATS, G.; PLANELLS, I. et al. Caracterización de Escherichia coli de los grupos filogenéticos A y B1 causantes de infección extraintestinal. Enferm. Infecc. Microbiol. Clin., v.24, p.483-489, 2006.

MOTA, R.A.; SILVA, K.P.C.; FREITAS, M.F.L. et al. Utilização indiscriminada de antimicrobianos e sua contribuição a multirresistência bacteriana. Braz. J. Vet. Res. Anim. Sci., v.42, p.465-470, 2005.

MOULIN-SCHOULEUR, M.; REPERANT, M.; LAURENT, S. et al. Extraintestinal pathogenic Escherichia coli strains of avian and human origin: Link between phylogenetic relationships and common virulence patterns. J. Clin. Microbiol., v.45, p.3366-3376, 2007.

PERFORMANCE standards for antimicrobial disk and dilution susceptibility testes for bacteria isolated from animals. Document Vet01-A4. Approved standard. 4.ed. [Wayne]: CLSI, 2013. v.33, n.7.

PONNUSAMY, P.; NATARAJAN, V.; SEVANAN, M. In vitro biofilm formation by uropathogenic Escherichia coli and their antimicrobial susceptibility pattern. Asian Pac. J. Trop. Med., v.5, p.210-213, 2012.

QI, L.; LI, H.; ZHANG, C. et al. Relationship between antibiotic resistance, biofilm formation, and biofilm-specific resistance in Acinetobacter baumannii. Front. Microbiol. v.12, p.483, 2016.

RAMOS, S.; SILVA, N.; CANIC, M. et al. High prevalence of antimicrobial-resistant Escherichia coli from animals at slaughter: a food safety risk. J. Sci. Food Agric., v.93, p.517-526, 2013.
REISNER, A.; KROGFELT, K.A.; KLEIN, B.M. et al. In vitro biofilm formation of commensal and pathogenic Escherichia coli strains: impact of environmental and genetic factors. J. Bacteriol., v.188, p.3572-3581, 2006.

SÁ, M.C.A.; GOUVEIA, G.V.; KREWER, C.C. et al. Distribution of PLD and FagA, B, C and D genes in Corynebacterium pseudotuberculosis isolates from sheep and goats with caseus lymphadenitis. Genet. Mol. Biol., v.36, p.265268, 2013.

SABATÉ, M.; PRATS, G.; MORENO, E. et al. Virulence and antimicrobial resistance profiles among Escherichia coli strains isolated from human and animal wastewater. Res. Microbiol., v.159, p.288-293, 2008.

STEPANOVIC, S.; VUKOVIC, D.; DAKIC, I.; SAVIC, B. et al. A modified microtiter-plate test for quantification of staphylococcal biofilm formation. J. Microbiol. Methods., v.40, p.175179, 2000.

RELATÓRIO ANUAL DA ABPA 2017. ABPA - Associação Brasileira de Proteína Animal. Online. Available in: <http://abpa-br.com.br/>. Accessed in: 5 Jan. 2017.

WANG, X.M.; JIANG, H.C.; LIAO, X.P. et al. Antimicrobial resistance, virulence genes, and phylogenetic background in Escherichia coli isolates from diseased pigs. FEMS Microbiol. Lett., v.306, p.15-21, 2010.

ZHANG, W.; FRANCIS, D.H. Genetic fusions of heat-labile toxoid (LT) and heat-stable toxin b (STb) of porcine enterotoxigenic Escherichia coli elicit protective anti-LT and anti-STb antibodies. Clin. Vaccine Immunol., v.17, p.1223-1231, 2010. 